\title{
The Revised Money Stock: Explanation and Illustrations ${ }^{1}$
}

\author{
by ALBERT E. BURGER and JERRY L. JORDAN
}

T

HE BOARD OF GOVERNORS of the Federal Reserve System recently revised the data for currency held by the public, demand deposits held by the public, and time deposits at all commercial banks. The revision includes semi-annual adjustments for new benchmark data on nonmember bank deposits and vault cash, and the annual recomputation of seasonal adjustment factors which are applied to each of the basic deposit and currency series.

In addition to the semi-annual benchmark and annual seasonal adjustments, a major aspect of the present revision is the correction of a measurement error in member bank demand deposits adjusted. This measurement error resulted mainly from international financial transactions flowing through U. S. agencies and branches of foreign banks, and subsidiaries of U. S. banks organized under the Edge Act to engage in international banking."

This note explains the revisions, illustrates their effect on the level and growth rates of money, and analyzes their significance for assessing recent monetary actions and their influence on the economy. In the Appendix, a sequence of transactions involving Edge Act corporations are presented in T-accounts to show how the money stock series was underestimated.

\footnotetext{
${ }^{1}$ The discussion in this note regarding the effects of transactions involving Edge Act corporations has benefited significantly from discussions with and papers made available by Irving Auerbach at the Federal Reserve Bank of New York and Edward R. Fry at the Board of Governors of the Federal Reserve System. Mr. Auerbach, Mr. Fry, and their respective associates are absolved of any remaining errors. For further discussion of the magnitude of the underestimation of the old money series, and the procedures used in the revision to correct for these measurement errors, see "Revision of the Money Stock," Federal Reserve Bulletin, December 1970, pp. 887-909.

2The Edge Act of 1919 amended the Federal Reserve Act Dermitting the Federal Reserve Board to charter corporations "for the purpose of engaging in international or foreign banking of other international or foreign financial operations ... either directly or through the agency, ownership, or control of local institutions in foreign countries. . . ."
}

\section{Reasons for the Revision}

\section{Seasonat Gechers}

Most weekly, monthly, and quarterly economic time series are subject to recurrent seasonal movements which are not related to broader underlying trends. In order to analyze movements in the series free of seasonal movements, statisticians have devised methods of identifying seasonal patterns and computing factors which are used to adjust the raw data. The seasonal pattem for a given series may change over time for various reasons, so it is desirable to recompute periodically the seasonal adjustment factors. The seasonal factors for components of the money supply and related series are recomputed annually.

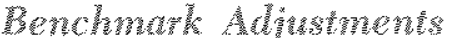

Twice each year insured nonmember banks submit their Reports of Condition (call reports) to the Federal Deposit Insurance Corporation. From these rew ports the Federal Reserve obtains information on nonmember bank deposits and vault cash. Between such reports the nonmember bank data on vault cash and deposits are estimated for purposes of computing the money stock. The receipt of new call report data provides a "benchmark" for improving the estimated nonmember bank data. Benchmark adjustments revised estimated nonmember bank deposits downward by $\$ 300$ million at the end of 1969 and by $\$ 900$ million for mid-1970.

\section{Revisons in Denand Devast Calculatons}

The U. S. money supply series, as compiled and published by the Federal Reserve System, consists of currency in the hands of the public and demand deposits held by the public at all commercial banks. The currency component of the money supply is obtained by subtracting vault cash of all commercial banks from total currency in circulation. ${ }^{3}$

\footnotetext{
${ }^{3}$ Data for vault cash of member banks are available on a weekly basis to the Federal Reserve. Data for vault cash of nonmember banks are estimated between semi-annual call reports. Data for total currency in circulation are available daily from Treasury and Federal Reserve statements.
} 
The demand deposit component of the money supply includes only demand deposits held by the nonbank public, that is, demand deposits at all commercial banks other than those due to domestic commercial banks (interbank demand deposits) and the U.S. Government. Also, "cash items in process of collection" and Federal Reserve float are deducted, to avoid double counting in measuring the amount of demand deposits the nonbank public knows that it holds (and hence infuences spending decisions).

The reason for deducting cash items in process of collection between domestic commercial banks can be illustrated by an example:

Suppose Mr. A writes a check for $\$ 100$ on his commercial bank $\left(\mathrm{CB}_{\mathrm{a}}\right)$. He then gives the check to $\mathrm{Mr}, \mathrm{B}$ who deposits it in his bank (CBb). While the check is in process of collection, that is, while $C B_{b}$ is waiting to receive a transfer of reserves from $\mathrm{CB}_{3}$, the funds involved appear as a demand deposit on the books of both $\mathrm{CB}_{\mathrm{a}}$ and $\mathrm{CB}$. Since checks do not clear instantaneously, gross demand deposits temporarily rise by $\$ 100$.

The money supply series measures the currency and demand deposits which the public knows it holds. Mr. A knows that he has $\$ 100$ less in his checking account. Therefore, the cash item in process of collection (the $\$ 100$ check of $\mathrm{Mr}$. A) is deducted to get a more accurate measurement of the money supply series.

"Cash items" (which appear as asset items in the balance sheets of banks waiting to receive payment) are also generated by certain international transactions. To the extent that the cash items resulting from the collection of funds relating to an international transaction (for example, the borrowing and repay ment of Eurodollars $)^{4}$ are matched by a liability such as a demand deposit of a foreign corporation, the computation of the demand deposit component of the money supply is the same as for cash items arising from purely domestic clearings.

However, certain other international transactions involving Edge Act corporations and U. S. agencies and branches of foreign banks - may not give rise to deposit liabilities on domestic commercial banks to offset the international cash items generated on the

\footnotetext{
"See Albert E. Burger, "Revision of the Money Supply Series," this Review October 1969 , p. 6-9, and "Revision of the Money Supply Series," Federal Reserve Bulletin, October 1969, pp. 787-803, for discussions of the effects of Eurodollar transactions on the money supply prior to nid1969, and a description of changes in Regulation $D$ to require certain transactions to be treated the same as other deposits subject to reserve requirements.
}

domestic commercial banks' balance sheet. ${ }^{5}$ A deposit of an Edge Act corporation or similar institution is treated by a U. S. bank as an interbank deposit and is therefore not included in the demand deposit component of the money supply. ${ }^{6}$ However, the cash items generated by the Edge Act transactions are included in the bank's total cash items, which are deducted from gross demand deposits.

The following example illustrates the effect of this treatment of Edge Act deposits on the money supply.

When a U. S. bank receives a check to be credited to the account of an Edge Act corporation, the bank enters the amount of the check in a liability account "due to bank" and also adds the amount to cash items in process of collection. Wher computing the money supply data, both the cash item and the "due to" account are deducted from gross demand deposits. The deduction of cash items is only appropriate when there is a counterpart deposit in the money supply data. Hence, it is double subtracting to include the cash item temporarily created by this transaction in the total cash items in process of collection to be deducted from gross demand deposits.

The volume of intermational transactions which creates these particular "due to" or interbank deposit accounts has been increasing rapidly in recent years. Thus, the old money supply series was subject to an increasing underestimation.

To correct for this measurement error in the dem mand deposit component of the money stock, data were collected from U. S. agencies and branches of foreign banks, and from Edge Act corporations, and added to gross member bank demand deposits ${ }^{7}$ As a result, the deduction of total cash items in process of

\footnotetext{
5The discussion in this article will emphasize transactions involving Edge Act corporations, but the reader should be aware that the discussion applies to certain other types of international institutions as well.

"This is the same as the liability account "due to domestic commercial banks" that appears on the balance sheet of a large correspondent bank with which another bank maintains deposits for clearing purposes (see Table I). "These transactions do not affect the required reserves of the commercial bank. The "due to" account increases the bank's demand deposits subject to reserve requirements, but the corresponding "cash item" is subtracted, thus demand deposits subject to reserve requirements are not affected.

TAccording to the article, "Revision of the Money Stock" Federal Reserve Bulletin, December 1970, p. 891: "The figures for deposits of Edge Act corporations are readily available from weekly reports submitted to the Federal Reserve Bank of New York in accordance with Regulation K. For agencies and branches of foreign banks, end-of-month deposit figures are available from reports submitted to the New York State Commissioner of Barking. However, it was necessary to
} 
collection (including those created by both domestic and international transactions) now provides a more accurate measure of "member bank demand deposits adjusted."

Computation of the demand deposit component of the money supply for a sample week is illustrated in Table I. Although the data in the table are approximations of the actual dollar changes, they reflect accurately the relative sizes of the revisions resulting from international transactions relative to benchmark adjustments. In the sample week, the addition of gross deposit liabilities of Edge Act corporations and other international banking institutions raised demand deposits adjusted by $\$ 7.9$ billion. Data for nonmember bank deposits, based on new benchmark data, were revised downward by $\$ 1.2$ billion. The net of these two corrections raised the demand deposit component of the money supply (before seasonal adjustment) by $\$ 6.7$ billion in the sample week.

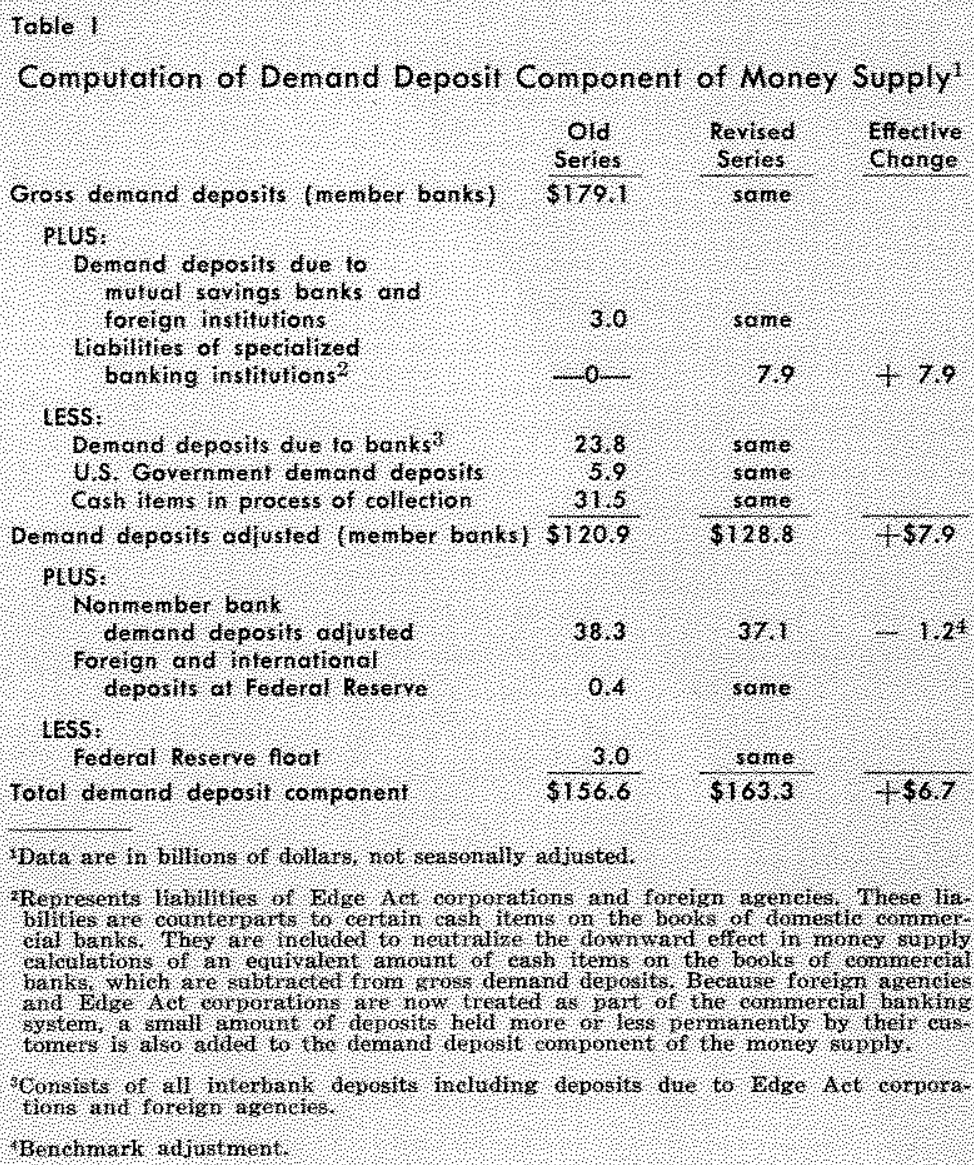

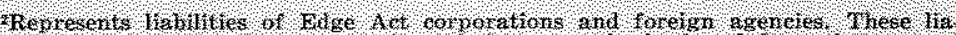
billties are colnterbarts

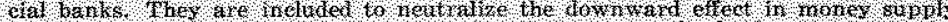

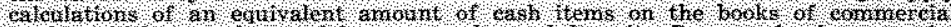

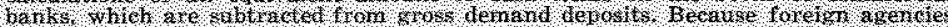

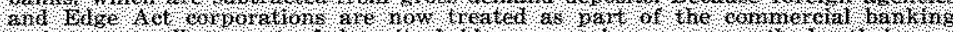

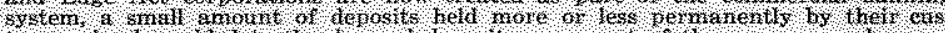

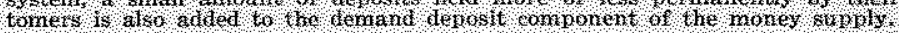

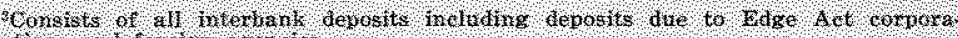
tions and torelgn at enders.

Benchnoth adjestritent

\section{Magnitude of the Revisions: Levels and Growth Rates of Money}

The accompanying chart of monthly data for the "revised" and the "old" money supply series from 1967 to the present illustrates the effects of the recent revisions." Underestimation of the old money supply series has been building up since mid-1968, and has widened more rapidly since mid-1969. However, comparison of the levels of the old and revised money supply data would not provide an accurate assessment of the effects of the recent revision on the influence of monetary actions in the past few years. Empirical

obtain additional data from agencies and branches to allow for checks written by them that were making for inappropriate cash items as a result of the intermediary role of these instifistions in intemational transfers. Such data have been reported daily since October 1 and will be available on a continuing basis."

8Two other much smaller sources of understatement of demand deposits resulting from banks practices in accounting for Eurodollar repayments were identified and eliminated by a change in accounting practices of certain banks.

97he recently revised money supply data are referred to as the "revised money supply series" and the former data are referred to as the "old money supply series" only as an aid to exposition in this article.

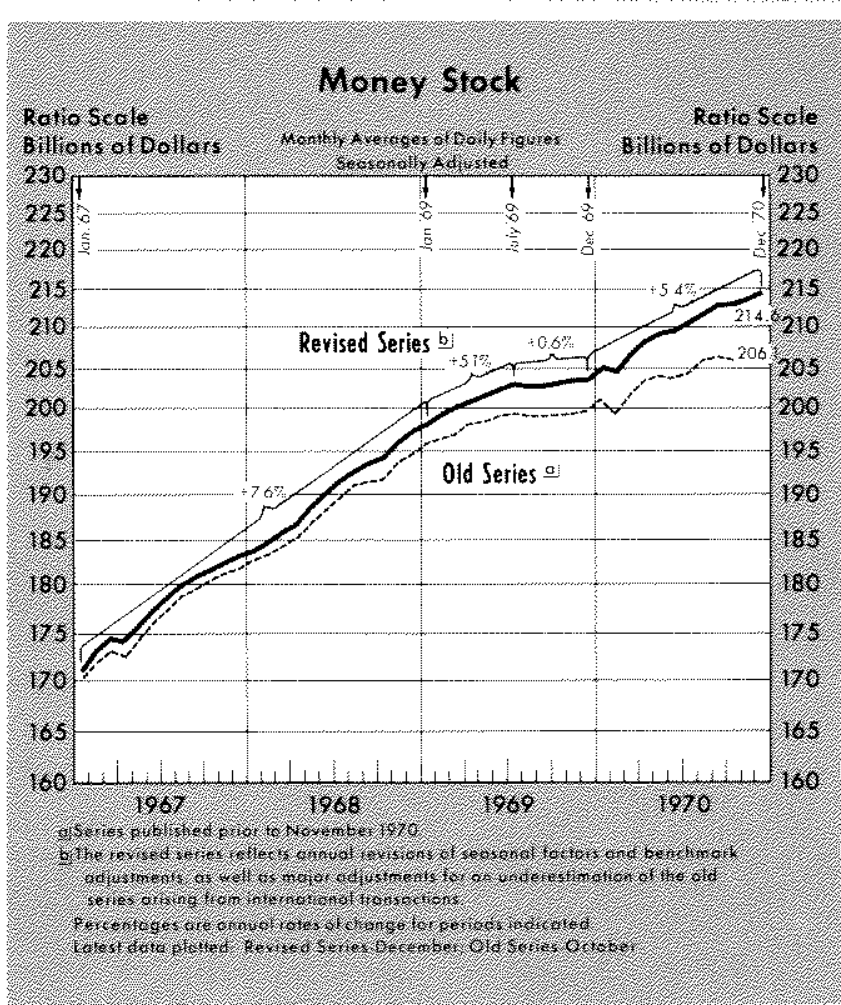




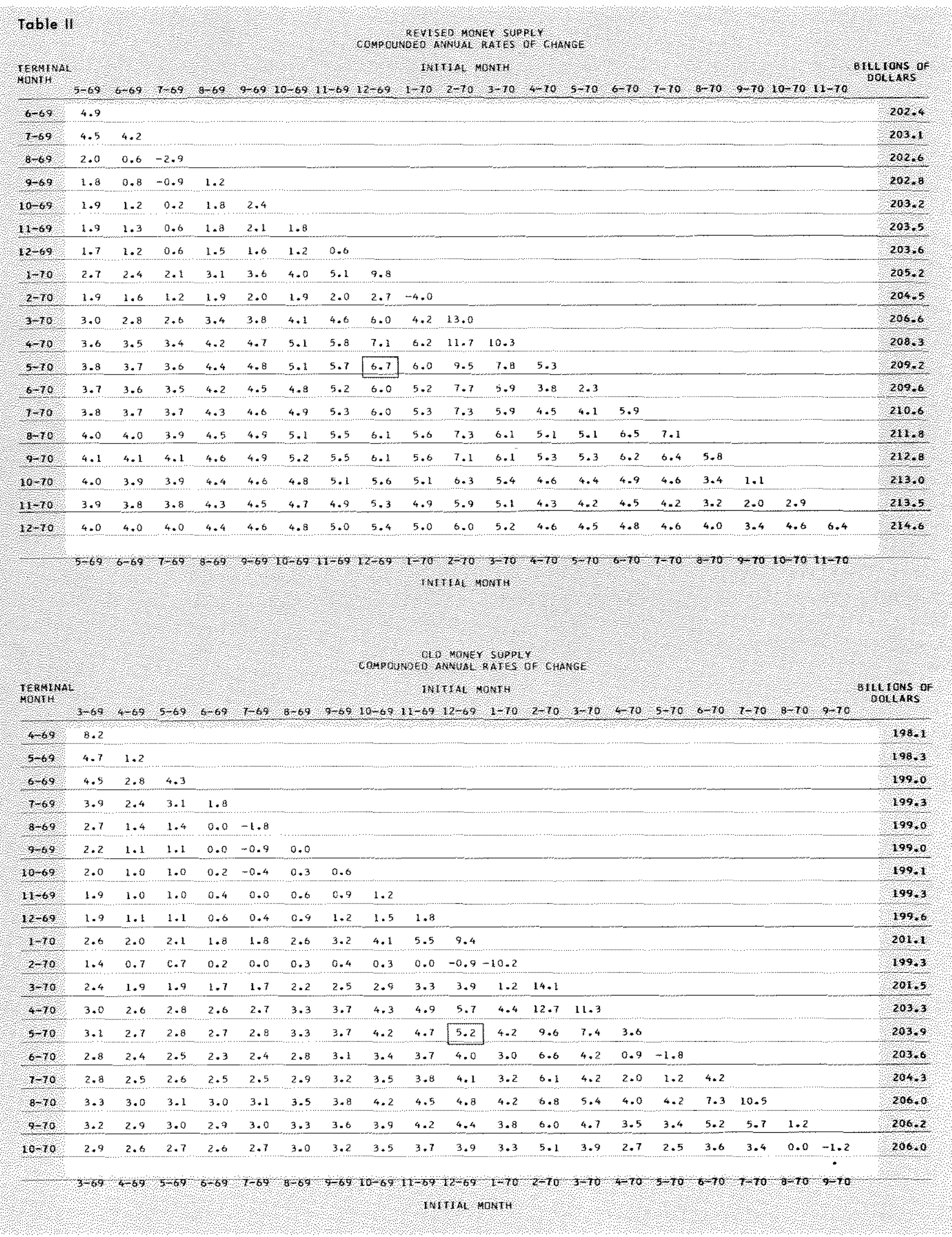


studies provide evidence that, for purposes of assessing the impact of monetary developments on the economy, it is appropriate to look at the changes in the rate of growth of money over the past twelve or more months.

The growth rates of money indicated by the revised series for 1968 and 1969 are not sufficiently greater than the respective growth rates indicated by the old series to warrant reassessment of the infuence of monetary actions during those two years. The growth of money in 1968 (from IV/67 to IV/68) was at a 7.4 per cent annual rate for the revised series, compared with a 6.8 per cent rate in the same period for the old series. Similarly, the revised money series rose at a 3.8 per cent rate from IV $/ 68$ to IV $/ 69$, not much faster than the 3.1 per cent rate of increase of the old series in that period.

The significance of the recent money supply revisions depends upon the impact of the revisions on the rates of change of money during 1969 and 1970 . Table II contains two "rate-of-change triangles" showing the growth rates of the revised and the old money supply series from various initial months to various terminal months in 1969 and 1970. To read the triangles, observe that the rate of change of the revised money supply series from December 1969 (on top and bottom horizontal axis) to May 1970 (on left vertical axis) was 6.7 per cent. The rate of change of the old money series in the same period was 5.2 per cent. With the aid of these triangles, the reader can choose any beginning and ending month he considers relevant, and compare the impact of the recent revi. sions on the growth rates of money.

\section{Revision of Money and Assessment of the Influence of Monetary Actions on GNP}

\section{An Analybol Apromen}

It is useful to employ a consistent analytic framework to analyze the implications of the revised money supply series on the implied course of total spending. Such an analytic framework is available in which changes in gross national product are statistically related to current and lagged changes in the money supply and high-employment Government expenditures. ${ }^{10}$

After obtaining a historical relation between changes in GNP on the one hand, and changes

\footnotetext{
10See Leonal Andersen and Keith Carlson, "A Monetarist Model for Economic Stabilization," this Review, April 1970 , pp. $7-25$, for discussion of a procedure whereby altemative constant rates of growth of money are used to simulate the relative impacts on projections of various measures of economic activity.
}

in money and Government expenditures on the other, it is possible to estimate the changes in GNP which are implied for the future under alternative assumed growth rates of money. The same assumptions about future Government expenditures are employed in each case, and it is assumed that there is no difference in other factors that infuence GNP. In such illustrations, the relative sizes of the projected changes in GNP under various assumptions concerning the future growth rate of money are important. The absolute level and the changes in the projected values for GNP are naturally subject to many factors not provided for in this procedure, such as the duration of an automobile industry strike.

\section{Monetery Actions in 7070}

As noted above, the growth rates of money for 1968 and 1969 , according to the revised series, were not much greater than the rates indicated by the old series. Consequently, assessment of the thrust of mon. etary actions during those two years is little affected by availability of the revised series as opposed to the old series.

The effect of one's assessment of the thrust of monetary actions in 1970 bears closer analysis. From IV $/ 69$ to III $/ 70$ the growth of money was indicated by the old series to have been at a 4.2 per cent annual rate, and is now shown to have been at a 5.5 per cent rate by the revised series. A relevant question to pose at this point is whether one's conclusion about the influence of monetary actions on the future growth of total spending, and hence prices and unemployment, would be much affected by the availability of the revised series.

By employing this approach, it is possible to test whether the growth rate of money for 1970 that appeared most likely to achieve a given growth rate of total spending would have been different at the end of 1969 , if the revised money series had been available at that time. Using statistical relations estimated from data available through the end of 1969 , projections were made of the growth paths of GNP for the four quarters of 1970 based on alternative assumed (constant) growth rates of the revised money series. These projections were then compared with similar projections based on the same assumed growth rates of the old money supply series. ${ }^{11}$

\footnotetext{
1Specifically, data for quarter-to-quarter changes in the old series from 1953 through 1969 were used to estimate a statistical relationship with quarter-to + quarter changes in GNP in the same period. Next, alternative assumptions about the growth rate of money during 1970 were used to
} 
The results were very close between each growth rate for the two series, indicating that the availability of the revised series at the end of 1969 would not have influenced substantially the selection of the desired growth of money for 1970. For example, based on the actual growth of the revised series during 1969 and an assumed constant 5 per cent rate of growth of this series during 1970, the growth of GNP was indicated to be 6.I per cent from IV/69 to IV $/ 70$. This compares with a 5.8 per cent growth of GNP for the same period as indicated by the actual growth of the old series in 1969 and an extrapolation of that series at a 5 per cent rate for 1970 .

It now appears that the actual growth of GNP during 1970 was somewhat less than 5 per cent. A 5 per cent rate of growth of either money series indicated a faster GNP growth during 1970. However, it should not be surprising that the actual growth of GNP fell short of the projections based on 5 per cent growth of money. The actual growth of GNP in the second half of 1970 was substantially dampened by the automobile industry strike, but, since there is no provision for the effects of a strike in this procedure, the actual should be less than the projected. Furthermore, the procedure is based on historic average relationships between changes in GNP and changes in money and Government expenditures during a period (from 1953) in which there have been several "business cycles" of varying lengths and degrees of severity.

\section{Monetury Actions in 1971}

Table III shows the projected quarterly changes in GNP from IV $/ 1970$ to IV $/ 1971$ as calculated for the revised money series and for the old series (based on data available through $\mathrm{II} / 70$ ). A 5 per cent amnual

obtain quarter-to-quarter changes in money for 1970 , beginning from the actual level of money (old series) in the fourth quarter of 1969 . These assumed changes in money in 1970 were then used, together with actual changes for money in 1969 , to compute the proiections of GNP for 1970 implied by each alternative growth rate of the old money series during 1970. Finally, the entire procedure was repeated wing actual changes in the revised money through 1969 to estimate a statistical relation with changes in GNP for the period, and to nake projections for 1970 .

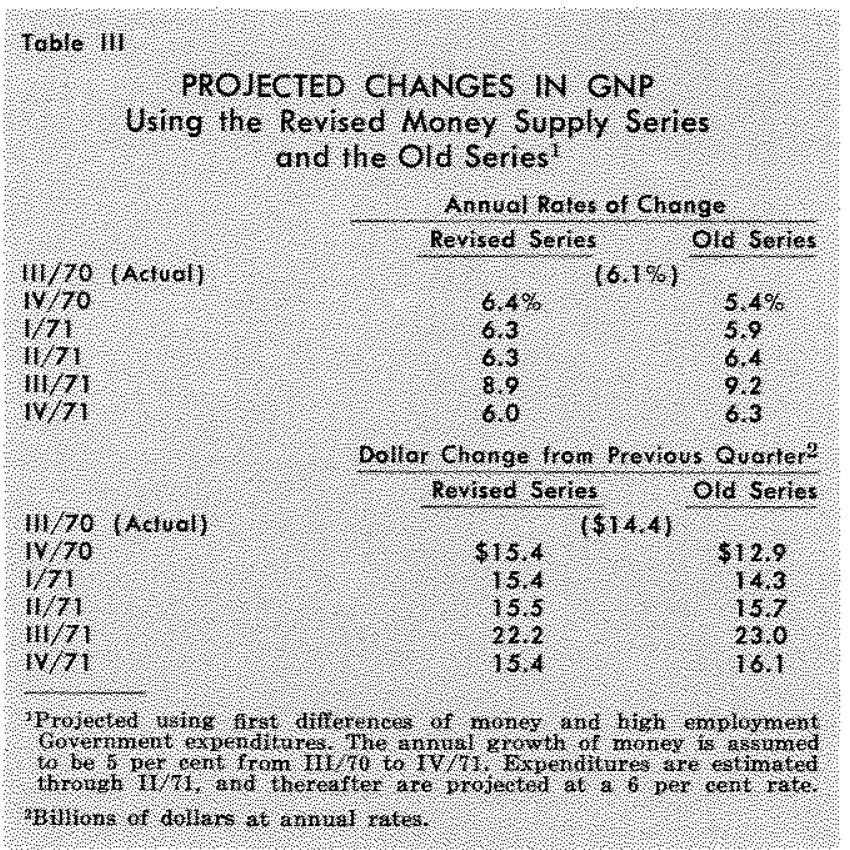

rate of increase was assumed in the respective money supply series from $I I I / 70$ to $\mathrm{IV} / 71$.

The table shows that GNP projections for IV/70 and $I / 71$, obtained using the revised money supply series, are higher than those obtained using the old money supply series. The GNP projections based on the old series for these two quarters are strongly influenced by the relatively slower growth of money in 1970 indicated by the old series. The GNP projections for the period from the fourth quarter of 1970 through the end of 1971 , using a 5 per cent growth rate of either money supply series, are approximately the same.

The revision of the money supply data has permitted a reassessment of the predicted strength of economic activity in the near future. However, the revision has not had a noticeable influence on predictions of the effects of monetary growth on economic activity over the coming year. On balance, if the goals of policy have remained unchanged, the comparisons presented here do not support any conjecture that monetary actions in the near future should be altered substantially from actions that were deemed appropriate based on the old series.

This article is available as Reprint No. 62 .

The Appendix to this article begins on the next page. 


\section{APPENDIX}

The following Appendix provides a technical analysis of how transactions involving Edge Act corporations caused an underestimation of the money stock series prior to the November 1970 revision. The example transactions used in this analysis should be viewed as a typical sequence of entries which would affect the measurement of the money stock.

The examples used draw heavily on a paper by Irving Auerbach of the Federal Reserve Bank of New York: "Edge Act Corporations: Some Problems For U.S. Banking and Monetary Statistics."

The purpose of this Appendix is to illustrate, through the use of "T - accounts," the type of transactions involving Edge Act corporations which have resulted in an understatement of the money stock. A key to understanding the examples used is to remember that one asset account of commercial banks (Cash Items in the Process of Collection) and one liability account (Due to Banks) are both deducted from the banks' gross (total) demand deposits in order to obtain the demand deposit component of the money stock. Also, demand deposits of foreigners at U.S. commercial banks, whether foreign individuals, banks, corporations, or governments, are included in the demand deposit component of the money stock.

In the illustration, a Chicago bank will borrow Euro. dollars for one day from a German bank, using the services of an Edge Act corporation, and then repay the amount through the Edge Act corporation (hereafter abbreviated to Edge Act). The Edge Act is located in New York City, but performs services for banks elsewhere in the United States as well as for Etropean banks.

For the illustration, it will be necessary to report the transactions of two New York banks. One New York bank is the "correspondent" of the German bank which is lending funds to the Chicago bank. The other New York bank is used by the Edge Act to clear funds, that is, to receive transfers from the account of foreign lending banks and to repay borrowed funds to the account of foreign banks. In other words, the Edge Act maintains a checking (demand deposit) account at the New York (clearing) bank for purposes of conducting international transactions as a service to U.S. and foreign banks.

The effects on the money stock when a U.S. bank borrows Eurodollars for one day using an Edge Act corporation will be illustrated by $\mathrm{T}$-account entries for three successive days.

\section{First Day}

A Chicago bank desires to borrow funds for a day, say $\$ 1000$, from a European bank (possibly a branch of a U.S. bank in Europe), and instructs its foreign branch bank (say in London or Paris) to borrow Eurodollars and have the funds paid to the Edge Act which will transfer the amount to Chicago. The foreign branch of the Chicago bank arranges the loan from a German bank, which notifies its New York correspondent bank to draw a check on its account payable to the Edge Act. The initial transaction for the first day is by the New York correspondent of the German bank, which issues an Officers Check ${ }^{1}$ payable to the Edge Act (and is delivered immediately to the Edge Act). This New York bank increases Officers Checks Outstanding and decreases the demand deposit account of the German bank, denoted as the Deposit of Foreigner account.

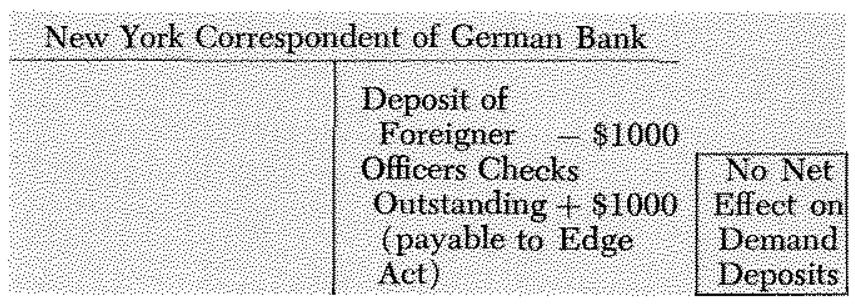

The Edge Act immediately takes the Officers Check to its clearing bank in New York and deposits the check to its own account. On its own books the Edge Act increases an asset account, Due from Bank (the New York correspondent) waiting for the check to clear, and also increases a liability account, Due to Bank (the Chicago bank).

1A change in the Federal Reserve Regulation D, effective July 31,1969 , requires that issuing banks include such items as "Officers checks," used in the borrowing and repayment of Eurodollars, in gross demand deposits. 
Edge Act Corpuration

\begin{tabular}{|c|c|c|}
\hline 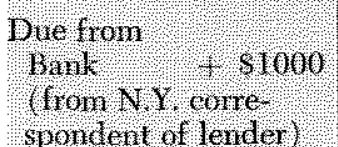 & 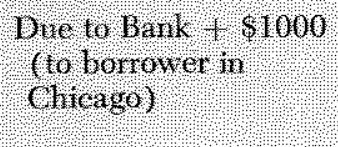 & $\begin{array}{l}\text { No Vet } \\
\text { Ereet on } \\
\text { Denumat } \\
\text { Deposis }\end{array}$ \\
\hline
\end{tabular}

At the same time the Edge Act's clearing bank increases an asset account, Cash Items in Process of Collection, and increases a liability, Due to Bank (Edge Act).

\section{New Yoik Clearing Bank of Edge Act Corporation}

Cash 1 ens in Proess of Collectiont $\$ 1000$

Dine to Bank + 51000 (to Idge Act)

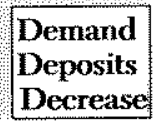

In the meantime, the Edge Act notifies the Chicago bank that it has borrowed $\$ 1000$ for one day from the German bank, and that collection of the funds is in progress, so the Chicago bank records an asset entry, Due from Bank (the Edge Act), and increases a nondeposit liability, Due to Foreign Branch.

\begin{tabular}{|c|c|c|}
\hline 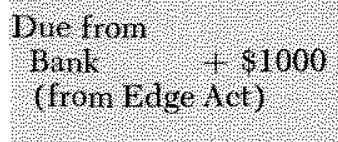 & 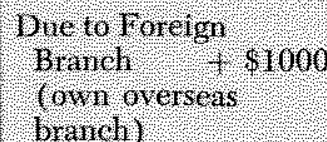 & $\begin{array}{l}\text { Wo No } \\
\text { Werte } \\
\text { Deposing }\end{array}$ \\
\hline
\end{tabular}

At the close of business on the first day the entries recorded in the above $T$-Accounts show that the money supply has decreased by $\$ 1000$. To see this, note that there is no effect on the net deposits of the New York correspondent of the German bank, since both Officers Checks and Deposits of Foreigners are included in the demand deposit component of money. Also, the deposits of the Chicago bank are not affected, since the liability account, Due to Foreign Branch, is not a deposit account and therefore does not enter into the computation of the money supply series, and the asset account, Due from Bank, does not affect the deposit component of money.' Futhermore, prior to the November 1970 revision of the money supply data, the transactions of Edge Act corporations were not considered in computing private demand deposits.

Finally, the clearing bank of the Edge Act has two entries that affect deposits. An increase in the liability account, Due to Bank, causes gross demand deposits to rise but, since these "interbank deposits" are subtracted from gross deposits to derive the demand deposit component of money, there is no net increase in demand deposits from this entry. Furthermore, the increase in the asset account, Cash Items in Process of Collection,

2Liabilities due to its own foreign branches are not considered deposits by the parent bank. The parent is not required to hold reserve balances against these liabilities (as they are against "due to domestic commercial banks"), and these deposits are not considered to be a part of the "private demand deposits in the hands of the public." causes a reduction of demand deposits of $\$ 1000$, since "Cash Items" are also deducted from gross deposits to obtain the money component. The decrense in deposits occurs because there was no of setting rise in net deposits. Stated simply, since the increases in both the asset and the liability accomts of the clearing bank are deducted from gross deposits, and since no other bank closed on the first day with a net increase in demand deposits, the demand deposit component of money has fallen $\$ 1000$.

\section{Second Day}

On the second day the Officers Check will clear, reserves will be transferred first from the New York correspondent bank to the cleating bank, and then to the Chicago bank. Meanwhile, the Chicago bank will initiate repayment of the loan through the Edge Act. At the end of the second day the demand deposits will still be reduced by $\$ 1000$. The day's transactions are shown in steps.

First, when the Officers Check clears, the New York correspondent loses reserves of $\$ 1000$ and reduces its liability account, Officers Checks Outstanding.

\begin{tabular}{|c|c|c|c|}
\hline \multicolumn{4}{|c|}{ 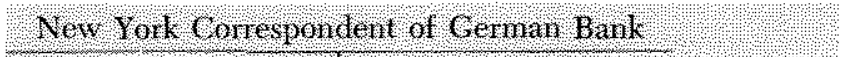 } \\
\hline nestres & ४४४ 1000 & 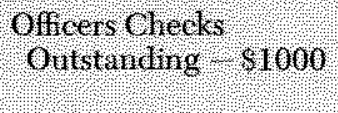 & $\begin{array}{c}\text { Demand } \\
\text { Deposits } \\
\text { Decrease }\end{array}$ \\
\hline
\end{tabular}

At the same time, the clearing bank gains the re serves and reduces its Cash Items in Process of Collection by $\$ 1000$.

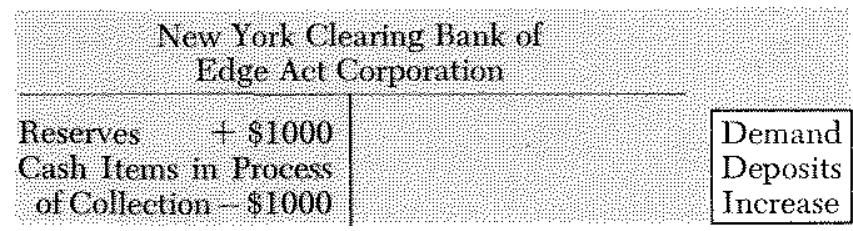

Upon receiving the reserves, the clearing bank initiates a transfer of funds to the Chicago bank, so the former bank loses the reserves it just received and rem duces a liability, Due to Bank.

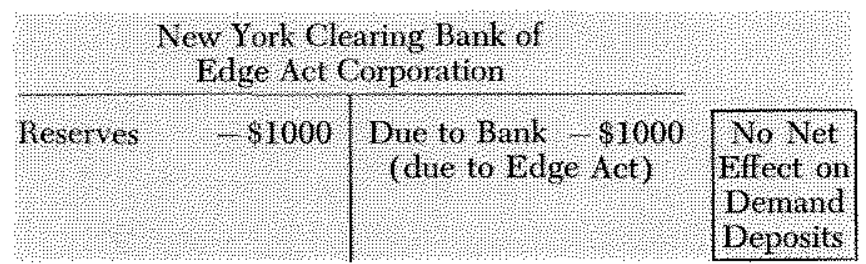

As this transfer occurs, the Chicago bank reduces an asset, Due from Bank, to match the increase in reserves, and the Edge Act clears the transaction from its books.

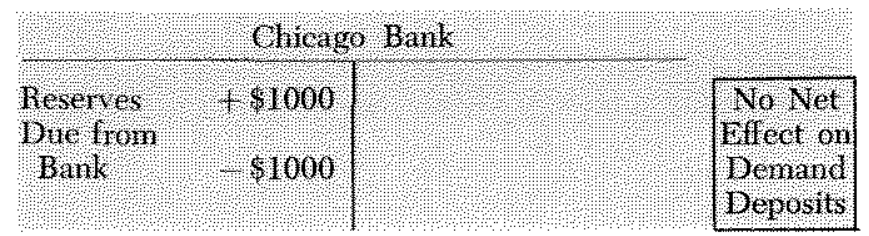

Page 13 


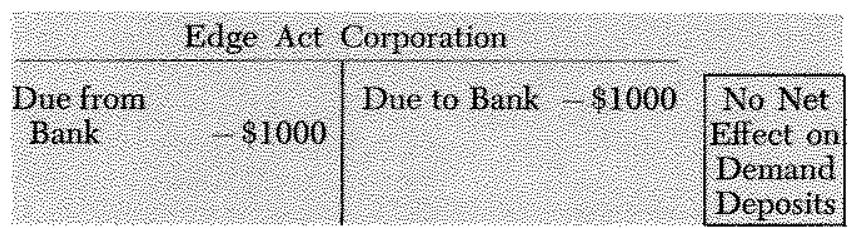

To initiate repayment of the borrowing of the previous day, the Chicago bank tells the Edge Act to make a deposit to the account of the German bank (at the latter's New York correspondent bank). As a provision for this repayment, the Chicago bank increases one liability account, Due to Bank (to the Edge Act), and decreases another liability, Due to Foreign Branch.

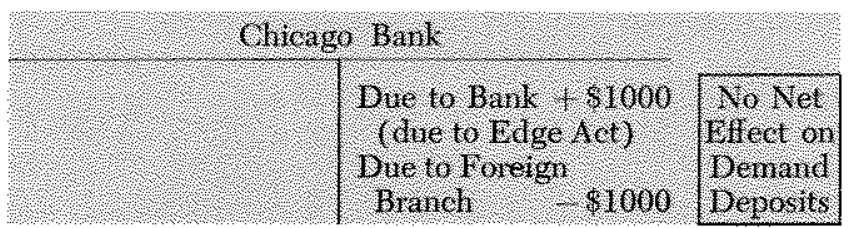

The Edge Act writes an Offcers Check drawn on its account at its clearing bank and increases an asset, Due from Bank (Chicago).

\begin{tabular}{|c|c|c|}
\hline$g$ & & \\
\hline 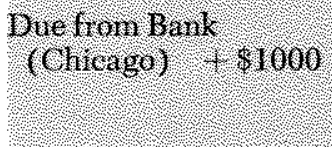 & 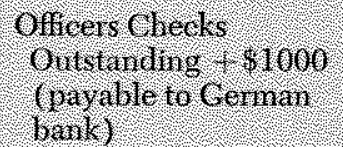 & 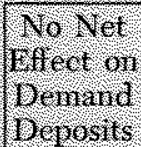 \\
\hline
\end{tabular}

The check is delivered to the New York correspondent which increases the German bank's account (Deposit of Foreigner) and increases its Cash Item in Process of Collection account.

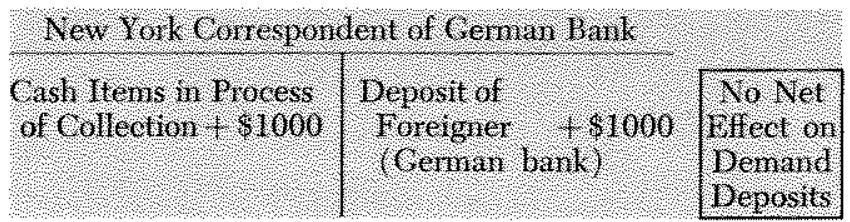

At the end of the second day, the New York correspondent has had an offsetting increase and decrease in deposits, with an increase in cash items, resulting in a decrease in the demand deposit component of money. The clearing bank of the Edge Act reduced its cash items, which caused the deposit component of money to rise at that bark, since there was no corresponding decrease in deposits (again, a change in the Due to Bank liability does not, by itself, result in a change in the deposit component of money). The entries of the Chicago bank are a reduction in the nondeposit account, Due to Foreign Branch, which has no effect at all, and an increase in the Due to Bank liability account, which increases this bank's gross demand deposits, then, it is subtracted out once again to compute the deposit component of money, resulting in no net effect. Again, the Edge Act entries did not enter into the computation of money.

On balance the above transactions for the second day do not result in a change in the demand deposit component of money compared to the first day. Since demand deposits were reduced at the end of Day 1 , they remain at the lower level at the end of Day 2.3

\section{Thind Duty}

As repayment of the Day 1 loan is cleared on the third day, the money stock will be restored to its original $\$ 1000$ greater level, assuming no new transactions through Edge Act corporations have occurred in the meantime. To cover the Officers Check writter by the Edge Act, the Chicago bank makes a transfer of funds to the account of the clearing bank of the Edge Act. The Chicago bank loses reserves and reduces its Due to Bank (Edge Act) liability account. The Edge Act reverses its prior entries to clear the transaction from its books, and the clearing bank of the Edge Act gains reserves and increases a liability acount, Due to Bank (to New York correspondent of German bank).
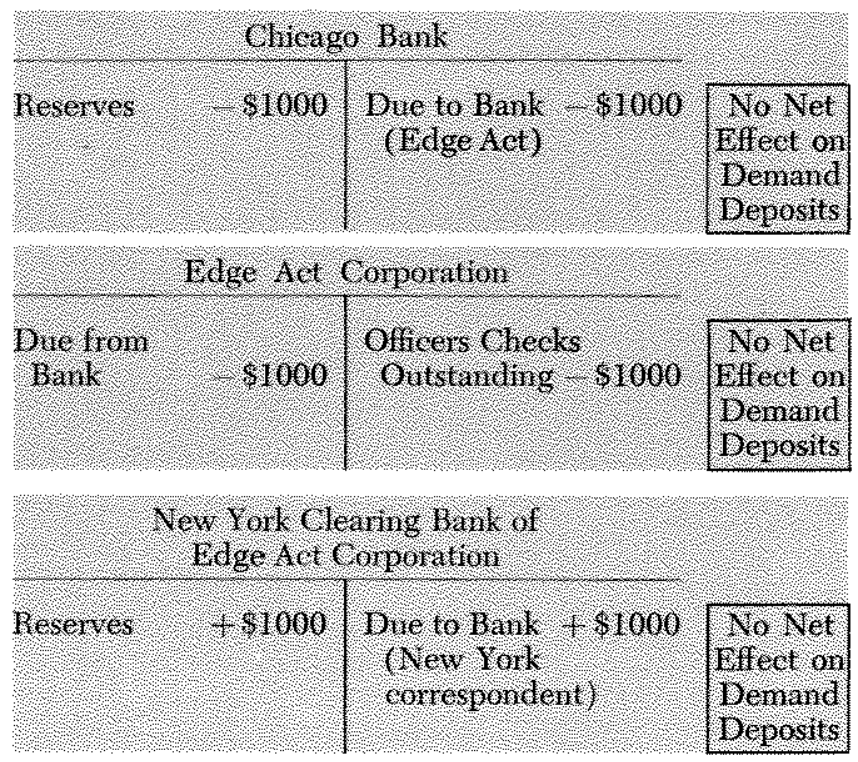

Upon receiving the reserves from the Chicago bank, the clearing bank makes a transfer of funds to the New York correspondent. The entries for the clearing bank are a decrease in reserves and a reduction of the account, Die to Bank. The entries for the New York correspondent of the German bank are an increase in reserves and a reduction of Cash Items in Process of Collection.

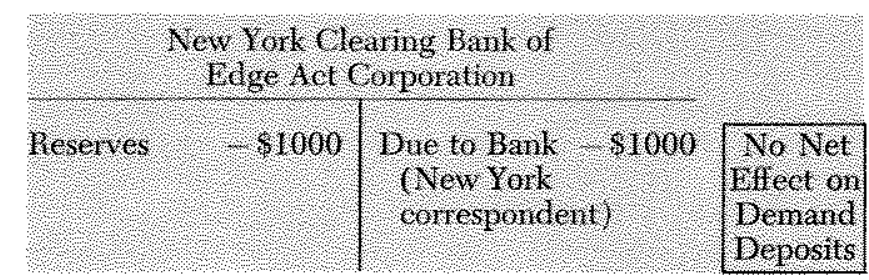

3The reader may note that if the Chicago bank had borrowed another $\$ 1,000$ on the second day all of the entries for the first day would be repeated in addition to the above entries for Day 2, and the deposit component of money would be understated an additional $\$ 1,000$. This point will be disctssed again at the end of this Appendix. 


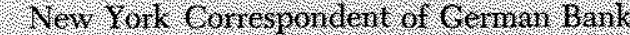

Reserves ? $\$ 1000$

Cash Itens in Trocess

of Collection $\$ 81000$

It should be clear that the deposit component of money rises at the New York correspondent bank, since the asset it deducts from gross demand deposits, Cash Items in Process of Collection, is reduced while there is no conresponding decrease in deposits. The entries for the Edge Act and the other banks have no effect. The demand deposit component of money is returned to the level at the beginning of the first day.

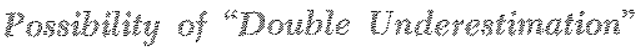

As indicated in footnote three of this Appendix, the example transactions involving an Edge Act corporation, which illustrate how an understatement of private demand deposits can occur, could result in deposits being understated by twice the amount of the Euro- dollar borrowings of the example (Chicago) bank, if the bank were to borrow the same amount every day, for one day. In the illustration used, the original amount borrowed from the example German bank was already included in the private demand deposit component of money. If the original $\$ 1000$ had been, for instance, a deposit at a foreign branch of the New York correspondent bank, and the amount was transferred from the branch to its New York parent when the loan was made, then the deposit component of money would not have been reduced on the first day. The fall in deposits at the clearing bank would have been matched by a temporary rise in deposits at the New York correspondent. The demand deposit component of money would then fall on the second day, as the amount is both cleared to Chicago and repayment is initiated through the Edge Act.

Similarly, if the original amount held by the German bank had been a time deposit at its New York correspondent bank, the demand deposit component of money would not have been reduced until the second day.

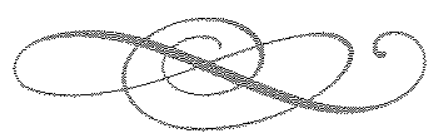

